\title{
Institutions, Infrastructure, and Trade
}

\author{
Joseph Francois* \\ Johannes Kepler Universität Linz, \\ Tinbergen Institute and CEPR \\ Miriam Manchin \\ University College London
}

April 2007

${ }^{*}$ Thanks are due to participants at the Econometric Society and European Economic Association annual meetings, various CEPR workshops, the European Trade Study Group annual conference, seminar participants at the Vienna Institute for International Economic Studies (wiiw), and workshops at the World Bank, IMF, and Kiel World Institute. This paper has benefited from support from DFID, and from an EU-funded research and training network on Trade, Industrialization, and Development. Address for correspondence: Joseph Francois, Johannes Kepler Universität Linz, Department of Economics, Altenbergerstrae 69, A-4040 LINZ, AUSTRIA. email: joseph.francois@jku.at. www.intereconomics.com/francois 


\title{
Institutions, Infrastructure, and Trade
}

\begin{abstract}
We work with a panel of bilateral trade flows from 1988 to 2002, exploring the influence of infrastructure, institutional quality, colonial and geographic context, and trade preferences on the pattern of bilateral trade. We are interested in threshold effects, and so emphasize those cases where bilateral country pairs do not actually trade. We depart from the institutions and infrastructure literature in this respect, using Heckman selection model-based gravity estimators of trade flows. We also depart from this literature by mixing principal components (to condense our institutional and infrastructure measures) with a focus on deviations from expected values for given income cohorts to control for multicollinearity. Infrastructure, and institutional quality, are significant determinants not only of export levels, but also of the likelihood exports will take place at all. Our results support the notion that export performance, and the propensity to take part in the trading system at all, depends on institutional quality and access to well developed transport and communications infrastructure. Indeed, this dependence is far more important, empirically, than variations in tariffs in explaining sample variations in North-South trade. This implies that policy emphasis on developing country market access, instead of support for trade facilitation, may be misplaced.
\end{abstract}

KEYWORDS: exports, trade, institutions, infrastructure, zero-trade, gravity model JEL CATEGories: O19, F10, F15 


\section{Introduction}

If trade matters, what can we then say about the countries that do not trade? Many countries in Africa, for example, are consistent underperformers. While "globalizers," as defined by Dollar and Kraay (2004), appear to be catching up with the OECD, the countries that are not are falling further behind, in both trade and growth terms. This begs the obvious question "why?" Why do they not trade, or why do they trade less relative to the recent set of globalizers? The issues involved are important ones. To address them, negotiators within the World Trade Organization have been given a "leave no country behind" mandate focused on integration of developing countries into the trading system. Emphasis has been placed on North-South tariffs, and there has been a massive mobilization of institutional resources (political, fiscal, legal and research-based) focused on trade promotion through liberalization of tariff and non-tariff barriers. The underlying magnitudes are highly relevant, as the mobilization of resources focused on trade policy, in a world of limited institutional resources, implies shifting away resources from other possible priority issues, like institutional development and improvements to basic infrastructure.

The renewed emphasis on growth through trade follows a tumultuous period of shifting perceptions on the role of trade in the empirical literature. Outward oriented policies emerged as a consensus growth prescription in the 1980s. This consensus was backed by cross-country studies of openness and growth. A pioneering attempt to classify trade regimes was conducted in an NBER study directed by Bhagwati (1978) and Krueger (1978). The common message carried from this work was that the degree of openness of the trade regime was positively corre- 
lated with export growth, which was in turn positively correlated with real GDP growth. A second large-scale attempt to classify countries by trade orientation was conducted by the World Bank (1987), reaching the same broad conclusion. What followed was a flood of cross-country empirical research linking trade to growth, and broadly supporting the paradigm view.

The consensus view was challenged in important papers by Edwards (1993) and Rodriguez and Rodrik (1999). The criticisms went to the foundations of the prior body of research, and were directed at the conclusions one can safely draw from cross-country studies. Rodriguez and Rodrik argued that we should not be comforted, but rather worried, by the apparent ability of highly disparate measures to capture the "same" relationship between openness and growth. Edwards argued that the basic approach to cross-country studies abstracted away from important factors better identified through studies of historical episodes. On the basis of such longer-term historical experience, both the Edwards and Rodriguez and Rodrik papers concluded that the role of trade had been overblown. However, the result has not been a paradigm shift, but rather more careful econometrics. As the dust settles, trade remains standing as a focus of attention.

The more recent body of work on export performance and economic growth has internalized earlier criticisms, and emphasis is now on the role of institutions and the record of experience within individual countries. Dollar and Kraay (2002) find that institutional quality is highly correlated with trade itself. They therefore focus on decadal changes in growth instrumented on changes in trade and institutions, and interpret their results as meaning that institutions and trade both matter in the long-run, while trade growth offers short-term advantages over insti- 
tutional improvements for fostering growth. In another paper, Dollar and Kraay (2004) examine episodes of liberalization, concluding that for individual countries that underwent recent trade liberalization episodes, expansion of trade translates into rising incomes and falling poverty rates. Wacziarg and Welch (2003) also focus on liberalization episodes, and also conclude that trade growth is linked robustly to growth and investment. Greenaway et al (2002) address a different criticism of Edwards and Rodriguez and Rodrik, linked to fundamental problems with the openness indicators used in the cross-country literature. They work with a dynamic panel and three openness indicators, finding that the trade openness relationship is robust to the earlier criticisms. Finally, while Rodrik et al (2004) do not find a direct impact of trade on incomes, they do find a more complex relationship between institutions, integration, and growth. Institutions can promote integration, while integration also has a (positive) impact on institutional quality. As they find institutions important for incomes, this suggests that trade can have an indirect effect on incomes. The consensus emerging is that trade does matter, but that it is linked to the context in which it is placed. Institutions matter, as does infrastructure. Hence, the development agencies have focused on facilitation aspects of development assistance, and emphasis is again being placed on institution building. At the World Bank, for example, Freund and Bolaky (2004) stress the importance of labor and business regulation in the trade-growth mechanism, while Chang et al (2005) offer panel evidence that the broad domestic mix of policy, institutions, and infrastructure plays an important role in moderating the impact of trade.

In part, the pattern of export performance is linked to the political economy of policy reform, institutional development and colonial history, development assistance, 
and the general North-South dialog. We can develop analytical models linking all these factors. At a more basic level though, there is also a need to quantify the relative magnitudes involved in the interaction between trade, infrastructure, and institutions. This is the issue explored here.

We do have evidence that improvements in transportation services and infrastructure can lead to improvements in export performance. Limão and Venables (2001) show that infrastructure is quantitatively important in determining transport costs. They estimate that poor infrastructure accounts for 40 percent of predicted transport costs for coastal countries and up to 60 percent for landlocked countries. Bougheas et al (1999) have analyzed the effects of infrastructure on trade through its influence on transport costs. Extending the DSF Ricardian trade model by endogenising transport costs and infrastructure formation their findings predict that for pairs of countries for which it is optimal to invest in infrastructure, a positive relationship between the level of infrastructure and the volume of trade takes place. Using a gravity model the authors provide evidence from European countries which supports the theoretical findings. Wilson et al (2004) have quantified the effects of trade facilitation by considering four aspects of trade facilitation effort: ports, customs, regulations, and e-business (which is a proxy for the service sectors of telecommunications and financial intermediation, which are key for all types of trade). The authors find that the scope and benefit of unilateral trade facilitation reforms are very large and that the gains fall disproportionately on exports.

Levchenko (2004) suggests that differences in institutional quality can themselves be a source of comparative advantage, finding that institutional differences across 
countries are important determinants of trade patterns. Using a gravity model, Anderson and Marcoullier (2002) find that bilateral trade volumes are positively influenced by the trading countries' institutional quality. Ranjay and Lee (2003) look at a particular aspect of institutions- enforcement of contracts-and its impact on the volume of international trade. The authors construct a theoretical model to show how imperfect enforcement of contracts can reduce the volume of trade in goods for which quality issues are important. Using a gravity equation the paper incorporates proxies for the enforcement of contracts and finds that the measures of contract enforcement affect the volume of trade in both differentiated and homogeneous goods, but the impact is larger for differentiated goods. Also employing a gravity equation, Depken and Sonora (2005) estimate the effects of economic freedom on U.S. consumer exports and imports for the years 1999 and 2000. They find that better institutional quality of the partner country has a positive effect on the amount of exports from the U.S. to that country.

In this paper we examine the influence of infrastructure, institutional quality, colonial and geographic context, and trade preferences on the pattern of bilateral trade. We are interested in threshold effects, and so emphasize those cases where bilateral country pairs do not actually trade. We depart from the institutions and infrastructure literature in this respect, using selection-based gravity modeling of trade flows. We also depart from this literature by mixing principal components (to condense our institutional and infrastructure measures) with a focus on deviations in the resulting indexes from expected values for given income cohorts to control for multicollinearity. ${ }^{1}$ Here, we work with a panel of 284,049 bilateral trade flows

\footnotetext{
${ }^{1}$ Recent related work involving thresholds, zeros in bilateral trade, and trade growth along extensive and intensive margins in a gravity context, includes Hummels and Klenow (2005), Evenett and Venables (2003), and Felbermayr and Kohler (2004).
} 
from 1988 to 2002. Matching bilateral trade and tariff data and controlling for tariff preferences, level of development, and standard distance measures, we find that infrastructure, and institutional quality, are significant determinants not only of export levels, but also of the likelihood exports will take place at all. Landlocked countries also do consistently worse. Our results support the notion that export performance, and the propensity to take part in the trading system at all, depends on institutional quality and access to well developed transport and communications infrastructure. Indeed, this dependence is far more important, empirically, than variations in tariffs in explaining sample variations in North-South trade.

The paper is organized as follows. In Section 2 we discuss our dataset and the basic estimating framework. Results are discussed in Section 3, and conclusions offered in Section 4.

\section{Methodology}

When examining the global pattern of bilateral trade flows, one striking feature of the landscape is that many country pairs do not trade. In our sample $42 \%$ of importer-exporter pairings had zero bilateral trade. Thus, apart from analyzing the effects of different factors on worldwide trade, we also concentrate our attention on factors that may explain why trade does not occur at all. While some factors might be expected to be important in the decision on how much to import, the same factors may be differentially important when the trader decides whether he or she will import at all. And yet, these two decisions clearly are linked. Only if the trader decides to import can trade volumes be observed and hence examined. 
Analyzing the determinants of trade flows without taking into account potential trade which does not take place between country pairs may bias results. At a minimum, unobserved trade may contain information about the factors driving bilateral trade relationships.

In this section we spell-out our estimation strategy. This involves specifying a sample selection model. Employing a sample selection model allows us to take account of the censoring process that leads to zero or missing bilateral trade flows. More precisely, in our estimating framework the outcome variable (the dependent variable in the second stage equation) is only observed if the defined selection criterion is met. In our case, the amount of the trade can only be observed if trade occurs. We therefore employ a sample selection estimation, combining the analysis of the probability of trade flows with the analysis of trade volumes. (Similarly, Felbermayr and Kohler (2004) employ a Tobit estimator to examine bilateral zeros.)

\subsection{Data}

We work with a panel of bilateral trade, trade policy, geographic characteristics, and income data spanning from 1988 to 2002. Our trade and tariff data were obtained from the UN/World Bank WITS system (World Integrated Trade Solution). The data in WITS come, primarily, from the UNCTAD TRAINS and COMTRADE systems and the World Trade Organization's integrated tariff database (IDB). The countries included in the sample are listed in the annex. ${ }^{2}$ There are

\footnotetext{
${ }^{2}$ While trade data are available for a wide range of country pairs, the available tariff data are more limited. For this reason, we utilize a standard WITS procedure of matching the nearest adjacent year to represent otherwise missing tariff data. Interpolation is then used for wider
} 
several country combinations for which trade is not reported. Following the recent literature, we assume that these missing observations from the database represent zero trade. (See Coe et al 2002, Felbermayr and Kohler 2004, Santos and Tenreyro 2005.) We use import data as it is likely to be more reliable than export data since imports constitute a tax base and governments have an incentive to track import data. Whenever import data was missing we used mirrored export data if it was available (this represented only half percent of the observations). Trade data is deflated using the reporter country's GDP deflator. Income and population are taken from the World Development Indicators database. Geographic data, together with dummies for same language and colonial links, are taken from Clair et al (2004). ${ }^{3}$ The distance data are calculated following the great circle formula, which uses latitudes and longitudes of the relevant capital cities.

We are ultimately interested in the dual role of institutions and infrastructure. Our data include indexes produced by the World Bank on infrastructure, and by the Fraser Institute for institutions. The institution indexes are from the "Economic Freedom of the World" (EFW) database. ${ }^{4}$ The EFW indexes are supplemented with robustness checks (with shorter panels) using data from Transparency International and Kaufmann, Kraay and Mastruzzi (2005). The EFW indexes are themselves based on several sub-indexes designed to measure the degree of 'economic freedom' in five areas: (1) size of government: expenditures, taxes, and enterprises; (2) legal structure and protection of property rights; (3) access to sound money: inflation rate, possibility to own foreign currency bank accounts; gaps. A further complication is when tariff data are never reported for a country pair. In order to obtain an approximate tariff value applicable between these country pairs we then utilize the average applied tariff for the reporting countries for a given year.

${ }^{3}$ http://www.cepii.fr/anglaisgraph/bdd/distances.htm

${ }^{4}$ http://www.freetheworld.com/download.html\#efw 
(4) freedom to trade internationally: taxes on international trade, regulatory trade barriers, capital marke controls, difference between official exchange rate and black market rate, etc.; and (5) regulation of credit, labor, and business. Each index ranges from 0 to 10 reflecting the distribution of the underlying data. Notionally, a low value is bad, and a higher value is good. We work with indexes for 1985, 1990, 1995, 2000, 2001 and 2002, with in interpolated values for years without values.

To measure infrastructure, we have taken data from the World Development Indicators database. This includes data on the percentage of paved roads out of total roads, on the number of fixed and mobile telephone subscribers (per 1,000 people), on the number of telephone mainlines (per 1,000 people), on telephone mainlines in largest city (per 1,000 people), telephone mainlines per employee, mobile phones (per 1,000 people), and freight of air transport (million tons per $\mathrm{km})$. Interpolation is used for years where no data are available.

Since both sets of indexes are highly correlated, we have used principal component analysis to produce a set of summary indexes. The results are reported in Table 1. Ideally, principal component analysis identifies patterns in data and based on these patterns it reduces the number of dimensions of the data without a lot of loss of information. From the results in Table 1, we take the first two components to produce four indexes; two institutional indexes, and two infrastructure indexes. These reflect between 70 percent and 77 percent of variation in the sample. From the weighting factors in the table, we interpret the first infrastructure index as measuring communications, and the second the physical transport system. We interpret the first institutional index as measuring general correspondence with the 
market-oriented legal and institutional orientation flagged by the Fraser indexes (in a sense the correspondence to the Anglo-U.S. socioeconomic model). The second institutional index then measures less interventionist systems with lower taxes and more market friendly regulations (deviations toward the Anglo-US social model).

\section{$2.2 \quad$ Estimating Equations}

We work with Heckman's selection model (Heckman 1979, Greene 2003), where we estimate the probability of trade occuring jointly with the determinans of the level of trade using maximum likelihood methods. This is based on the following two latent variable sub-models:

$$
\begin{aligned}
& M_{1}=\alpha^{\prime} X+u_{1} \\
& M_{2}=\beta^{\prime} Z+u_{2}
\end{aligned}
$$

where $X$ is a $k$-vector of regressors, $Z$ is an $m$-vector of regressors, and $u_{1}$ and $u_{2}$ are the error terms which are jointly normally distributed, independently of $X$ and $Z$, with zero expectations. The variable $M_{1}$ is only observed if $M_{2}>0$. The variable $M_{2}$ takes the value of one if $M_{1}$ is observed, while it is 0 if the variable $M_{1}$ is zero or missing. In our regressions $M_{1}$ is the value of imports, while $M_{2}$ is a dummy variable taking the value one if trade occurs while zero otherwise. The first equation shows how the value of imports is affected by different factors, while the second gives some insight into why trade occurs at all between two partner countries.

In specifying the underlying structure of equation (1), or identically the right 
hand side variables that make up $X$, we follow the gravity-model based literature. There are many paths that lead to the now standard functional relationship we use here, inclusive of importer and exporter fixed effects and economic distance terms. (See Evenett and Keller 2002; Anderson 1979; Anderson and Marcoullier 2002, Anderson and van Wincoop 2003; and Deardorff 1988.) Such an estimating framework can, for example, be interpreted as a reflection of first order conditions given an equilibrium dataset for goods trade. Interpreted this way, the gravity equation maps relative variations in bilateral trade flows to the determinants of relative variations in price for bilateral country pairs. Price determinants in the empirical literature include bilateral variables like tariffs, geographic distance, as well as country-specific factors for both importer and exporter. To highlight the basic properties inherent in such a specification of trade flows in a relatively parsimonious manner, and so to arrive at our estimating equation, we will start from trade based on CES preferences. At a macro-economic level, models of bilateral trade based on CES preferences, like the Obstfeld-Rogoff model, lead immediately to the gravity relationship (Obstfeld and Rogoff 1995). So do CES-based multi-sector models based on either firm or national product differentiation (Hertel 1997). In formal terms, we start with CES preferences for imports defined over goods originating from $r$ regions as in equation (3).

$$
Q=\left[\sum_{i=1}^{r} \alpha_{i} M_{i}^{\phi}\right]^{1 / \phi} 1>\phi>0
$$

It follows immediately from first order conditions for a constrained optimization solution of (3) that import demand will be as defined by equation (4),

$$
M_{i}=Q\left(\frac{\alpha_{i}}{P_{i}}\right)^{\sigma} P^{\sigma-1}
$$


where $\sigma=1 /(1-\phi)$. Similarly, under firm level differentiation (as in the ObstfeldRogoff implementation of Ethier-type production) and standard large-group and symmetry assumptions (Francois and Roland-Holst 1997), with $n_{r}$ firms located in each of $r$ regions and import demand specified over firm-based varieties, the CES aggregator can be written as in equation (5).

$$
Q=\left[\sum_{i=1}^{r} \alpha_{i} n_{i} \bar{x}_{i}^{\phi}\right]^{1 / \phi}=\left[\sum_{i=1}^{r}\left(\alpha_{i} n_{i}^{1-\phi}\right) M_{i}^{\phi}\right]^{1 / \phi}=\left[\sum_{i=1}^{r} \gamma_{i} M_{i}^{\phi}\right]^{1 / \phi}
$$

In equation (5), the term $\gamma$ reflects a combination of CES weights and number of firms, aggregated by country, while $\bar{x}_{i}$ is the average quantity consumed from each firm in a region. The number will be fixed or given in a particular cross-section, as we are then working with an actual (particular) market outcome. Comparison of equations (3) and (5) should make it clear that in both cases we can work with equation (4). Starting with equation (4), if we take logs we have the following representation of import demand:

$$
\ln M_{i}=\ln Q+\sigma \ln \alpha_{i}-\sigma \ln P_{i}+(\sigma-1) \ln P .
$$

Defining the $f o b$ price from country $i$ as $P_{i}^{*}$, then the landed or cif price will then be

$$
P_{i}=P_{i}^{*}(1+\tau) G
$$

In equation (7), the term $\tau$ represents trade taxes, while the term $G$ represents factors linked to the cost of trade, such as administrative burdens, and also transport and communications costs linked to physical infrastructure and physical distance. 
We can make a substitution of equation (7) into equation (6) to get a variation of the now standard ${ }^{5}$ representation of the basic gravity equation with exporter and importer dummy variables:

$$
\begin{aligned}
\ln M_{i, j} & =\ln Q_{j}+\sigma \ln \alpha_{i, j}-\sigma \ln P_{i}^{*}-\sigma \ln \left(1+\tau_{i, j}\right)-\sigma \ln G_{i, j} \\
& =D_{j}+D_{i}-\sigma \ln \left(1+\tau_{i, j}\right)-\sigma \ln G_{i, j} .
\end{aligned}
$$

In arriving at the final version of equation (8) we have introduced indexing by source and destination, while also imposing similar preferences (i.e. similar CES weights) across importers with respect to exporters. Importer and exporter effects (our dummy variables $D_{i}$ and $D_{j}$ ) sweep up a range of country specific effects, like fob price, the linkage between income level and total demand $Q$, and the linkage in firm level differentiation models between size of total output in a country and the number of firms included in the term $\gamma$. Note that when we interpret the gravity model as following from first-order conditions, we can hold these various country-specific effects as fixed, as we are working with data reflecting a particular set of actual market outcomes. This lets us focus on the determinants of bilateral variations in import demand. For this reason, an extremely reduced form gravity model can be useful for estimating trade-cost related effects linked to variables like distance, customs union membership, and bilateral tariff rates. When we replace the summary exporter and importer dummies (as we will do here) by explicit measures of country specific variables like GDP, country size, governance, infrastructure and the like, we are then also able to quantify their impact on trade

\footnotetext{
${ }^{5}$ The Anderson and van Wincoop (2003) specification calls for a mix of bilateral resistance terms in a non-linear estimating equation. However, Feenstra (2004) shows that including country-specific effects generates the same results as the Anderson and van Wincoop results with little loss of efficiency. Given our focus in the estimation on exporter-specific measures, we follow Feenstra, with modifications to allow for exporter variables as discussed in the text.
} 
flows as well.

Equation (8) is relatively general, and is used in much of the current literature. This includes Mtys (1997) and Francois and Woerz (2006). For our purposes though, we cannot use both fixed importer and exporter effects in our panel regressions. This is because we want to work with time-varying country-specific variables related to institutions and infrastructure, which precludes the use of time-varying country dummies. Instead, we include time specific and reporter (importer) country specific dummies. This forces us to include variables that are likely to be important determinants of the reduced-form exporter effects dummies in equation (8). From the gravity literature, we expect trade flows to be a function of importer and exporter size and income, as well as of determinants of bilateral trade costs like distance and tariffs. We also include variables of interest for the present exercise. These are measures of infrastructure and institutional aspects of importers and exporters that we expect to impact on trading costs. In terms of our sample selection model we specify the following:

$$
\begin{aligned}
\ln M_{i, j, t}= & \alpha_{0}+\alpha_{1} \ln p_{-} p c G D P_{j, t}+\alpha_{2} \ln r_{-} p c G D P_{i, t}+\alpha_{3} \ln p_{-} P O P_{j, t} \\
& +\alpha_{4} \ln r_{-} P O P_{i, t}+\alpha_{5} T_{i, j, t}+\alpha_{6} \ln \text { dist }_{i, j}+\alpha_{7} \text { landlocked }_{i} \\
& \alpha_{8} \text { comlang_ethno }_{i, j}+\alpha_{9} \text { colony }_{i, j} \\
& +\alpha_{10} \ln I N F 1_{j, t}+\alpha_{11} \ln I N S 1_{j, t}+\alpha_{12} \ln I N F 2_{j, t} \\
& +\alpha_{13} \ln I N S 2_{j, t}+u_{1}
\end{aligned}
$$


and for the selection estimation we assume that $M_{i, j, t}$ is observed when we have

$$
\begin{aligned}
& \beta_{0}+\beta_{1} \ln p_{-} p c G D P_{j, t}+\beta_{2} \ln r_{-} p c G D P_{i, t}+\beta_{3} \ln p_{-} P O P_{j, t} \\
& +\beta_{4} \ln r_{-} P O P_{i, t}+\beta_{5} \ln \text { dist }_{i, j}+\beta_{6} \text { landlocked }_{i} \\
& +\beta_{7} \text { comlang_ethno }_{i, j}+\beta_{8} \text { colony }_{i, j}+\beta_{9} \ln I N F 1_{j, t} \\
& +\beta_{10} \ln I N S 1_{j, t}+\beta_{11} \ln I N F 2_{j, t}+\beta_{12} \ln I N S 2_{j, t}+u_{1}>0
\end{aligned}
$$

In equations (9) and (10), $u_{1}$ and $u_{2}$ have correlation $\rho .^{6}$ Equation (9) assesses the determinants of the bilateral trade and shows the main factors influencing the amount of trade, given trade occurred between the two trading partners. Equation (10) sets out the selection criteria and provides information on the factors that determine whether or not we observe trade between country pairs.

All of our right-hand side variables are summarized in Table 2. $M_{i, j, t}$ is country $i$ imports from country $j$ at time $t$. As a proxy for market potential, $P O P$ is included for partner (exporter) and reporter countries, as well as per-capita income $p c G D P$. These are standard gravity variables, as is distance dist and tariffs T. For bilateral import protection, we use applied tariffs, $\ln T_{i, j, t}=\ln \left(1+\tau_{i, j, t}\right)$. $\tau_{i, j, t}$ indicates the applied tariff rate offered by importer $i$ to exporter $j$ in period t. As reporter specific fixed effects (non time-varying) are included in the regressions and these are highly correlated with the tariff data we regressed the log of the tariffs on the reporter dummies and retained the residuals. These residuals are used for the regressions and provide a measure of the effects of bilateral tariffs given other reporter specific characteristics. Distance is well established in

\footnotetext{
${ }^{6}$ Note that while included in the levels model, $\ln (T)$ is not included in the selection model. This choice is based on specification tests (it is never significant in our selection models), as reflected in our estimation for Table 6 .
} 
the gravity equation literature. (See for example Disidier and Head 2003, and Anderson and van Wincoop 2003.) The dummy landlocked takes the value of one if the importing country is landlocked and zero otherwise. Landlocked countries are expected to have higher transportation costs than countries with similar characteristics not being landlocked. Limão and Venables (2001) estimate that a representative landlocked country has transport costs approximately $50 \%$ greater than does a representative coastal economy.

To capture historical and cultural linkages between trading partners several zeroone type dummy variables are included in the estimating equation. The variable colony takes the value of 1 if the exporting country $j$ was a colony of the partner country $i$. Finally, a separate dummy, comlang_ethno captures if the traders of the two partner countries can speak the same language, or generally share the same linguistic heritage.

Since both the factors proxying institutional quality of the partner country and the factors measuring the availability of infrastructure are highly correlated with income per capita and population, we regress our indexes against per-capita income and population and take the residuals as representative of deviations from incomeconditional expected values for each of the four indexes.

$$
\begin{aligned}
\ln I N D E X_{k, j, t}= & \alpha_{k, 0}+\alpha_{k, 1} \ln p c G D P_{j, t}+\alpha_{k, 2}\left(\ln P O P_{j, t}\right) \\
& +e_{j, t}, k=1 . .4
\end{aligned}
$$

These deviations $e_{j, t}$ then correspond to the index values in equations (9) and (10). OLS estimates of equation (11) are reported in Table 3. Both the first infrastructure variable, mapping to communications infrastructure, and the second variable 
capturing physical transportation are highly correlated with income. Roughly half of the variation in the institutional variables can be represented by income levels.

\section{Results}

Estimation results for variables of interest for the full sample and for sample splits are reported in Table 4 . In Table 4 we report marginal effects from ML-based Heckman selection model regressions. Separate OLS estimates for equation (9) are reported in Table 5 and tobit estimates are reported in Table 6. Focusing on the simultaneous ML-based estimates in Table 4, for the full sample communications infrastructure $(I N F 1)$ is significant with the expected sign. This holds both for the first equation (probability of trading or not) and for the second equation (the value of trade given that trade does occur). Again, there is a broad correspondence with priors. Transport infrastructure matters, and significantly, both for trade volumes, but also for the probability that trade occurs at all. The quality of general governance has a positive effect on both trade and the probability that trade occurs. Moreover, countries with lower degrees of government intervention in the economy have higher exports than otherwise. Again, this is not surprising. We will focus shortly on the economic magnitudes of these effects. They are actually quite large.

In the remaining columns of the table, we turn to various splits on our full sample. What we are looking for is evidence of a differential role, at the margin, for institutions and infrastructure depending on the level of development. The second column of Table 4 focuses on South exports to the North, the third on 
LDC exports to the North, and the last on South-South trade. The exporters in the last three sets of results are therefore restricted to low and lower middle income countries according to World Bank definitions, and hence exclude high income countries. The importers exclude low and lower middle income countries in the second and third sets of results, high income in the fourth. For developing countries overall, the message is again that infrastructure matters. This applies not only to physical transportation, but also to communications infrastructure. ${ }^{7}$ General governance has a positive effect on trade, and a smaller presence by the state in the economy of the exporter does increase exports somewhat. However, the governance result changes somewhat for the poorest countries. We will explore this point further when we develop interaction terms. An important point to make at this juncture though is that relative to the average level for its income cohort, increased regulation and size of government improved performance for the least developed countries. This points to an undersupply of government services at the lowest income levels in the sample. This is further manifested when we turn to the South-South sample split, where we find that the involvement of the state in the economy has an ambiguous impact on trade. While it positively influences the probability of trading, it has a negative effect on the value of exports. We again get an unambiguous message about infrastructure though. It is a significant determinant of trade both for the probit results, and also for the trade volumes given that trade occurs.

If we move from statistical significance to economic relevance, what do our coefficient estimates tell us? We address this question in Table 7 . The table reports

\footnotetext{
${ }^{7}$ This confirms the pioneering results of Boatman (1992). Boatman found that not only general export levels, but also the technology composition of exports, hinged critically on the quality of the telecommunications system. In a world with globally integrated production systems, this result is intuitively appealing.
} 
estimated percent variation in expected trade related to a one-standard deviation variation in infrastructure and institutions around mean values. Values are normalized (and so can be gauged as rough measures of the contribution to overall sample variation in exports, measured by the coefficient of variation.) In general, the combination of institutional and infrastructure variation are much more important to the pattern of bilateral trade volumes than is bilateral protection. In the North-South sample split, for example, infrastructure variation implies marginal variations in the volume of trade of roughly $11 \%$ around the mean for communications and $7 \%$ percent for transport, compared to $2 \%$ for tariffs. For the least developed countries, transport is more important than communications linkages. Overall, variations in infrastructure appear to explain far more variation in the relative volumes of North-South trade than do variations in North tariffs on imports from the South. For the LDC sample, tariffs are more important, though even here the combined effect of infrastructure and institutions implies 2.5 times more variation in the sample than tariffs do. Turning finally to South-South trade, tariff effects are again roughly the same as for the full sample split, while the role of infrastructure is roughly comparable as well.

To explore further the differences following from sample splits in Tables 4-7, in Table 8 we report a full sample regression that includes an interaction term for each index $(I N F 1, I N F 2, I N S 1, I N S 2)$ with respect to per-capita income. Associated marginal effects are shown in Figures 1 and 2. Given the combination of level and interaction effects, and variations in sign, it is hard to interpret the results without some knowledge of the range of income linked to the coefficient estimates. For this reason, in Figures 1 and 2 we plot estimated marginal effects (from the level and interaction terms in Table 8) from the coefficients reported in Table 8, 
linked to variations in institutions and infrastructure. Given the underlying model, these marginal effects can be interpreted as variations relative to the mean value at a given income level. In other words, they quantify the observed improvement in export performance when a country has better transport infrastructure, for example, relative to other countries at the same income level.

From the figures, variations in basic transportation are much more important at low income levels in explaining variations in trade performance than at higher income levels. The opposite holds for communications, which grows increasingly important, particularly as a country reaches the middle income range. We also get a mixed message with institutions. While at high incomes a larger size of government, with greater regulation, is bad for exports, this is much less so at lower income levels. This is consistent with the North-LDC results from the split sample regressions reported in Table 4 .

As a check on the robustness of our results, we also report the regressions using other institutional variables from alternative sources, based on full sample specification in Table 4. These measures are generally available for a shorter time span than our primary indicators, leading to a truncation of our panel. Corresponding results are shown in Table 9. Instead of using principal component analysis we have included these institutional variables separately in the regressions. Since these variables are also correlated with income of the country we follow the previously used methodology and regress the institutional variables on per-capita income and population and take the residuals as representative of deviations from income-conditional expected values for each of the four indexes.

Alternative variables measuring institutional quality were obtained from two sources. 
A proxy for the level of corruption was obtained from the Transparency International Corruption Perceptions Index for the period 1996-2003. The Index ranks countries in terms of the degree to which corruption is perceived to exist among public officials and politicians and focuses on corruption in the public sector and defines corruption as the abuse of public office for private gain.

Several other variables measuring the quality of institutions and governance were taken from Kaufmann, Kraay and Mastruzzi (2005). The authors estimate six dimensions of governance covering 209 countries and territories for five time periods: 1996, 1998, 2000, 2002 and 2004. Data for the year 1997, 1999, 2001 and 2003 were interpolated. The variables were used to check the robustness of our previous results: government effectiveness (measuring the competence of the bureaucracy and the quality of public service delivery), political stability (measuring the likelihood of violent threats to, or changes in, government, including terrorism), regulatory quality (measuring the incidence of market-unfriendly policies), rule of law (measuring the quality of contract enforcement, the police, and the courts, as well as the likelihood of crime and violence), voice and accountability (measuring political, civil and human rights). The six indicators are measured in units ranging from about -2.5 to 2.5 , with higher values corresponding to better governance outcomes. The results using the variables measuring different aspects of institutional quality and the index proxying the importance of corruption in the public sector confirm the findings in the previous section. All the alternative institutional variables have important positive impact on both the value of exports and the probability of exporting. 


\section{Summary}

Recent empirical evidence supports the characterization of developing countries as belonging either to a cohort of countries that are deepening linkages with the global trading system (globalizers), or to those that are not (Dollar and Kraay, 2004). The globalizers (like China and India) have seen rapid growth in trade, and this growth has been linked to accelerating growth rates, pushing incomes on a catch-up path with the OECD and driving poverty rates down in the process (Salai-Martin, 2006). At the same time, there is another cohort of developing countries (many in Africa) with a very different story to tell. For a raft of reasons, they are being left behind. While trade and growth may be wrapped up in a positive cycle for some countries, those left behind have not experienced rapid trade growth, or the related mechanisms that signal deeper integration into the global economy.

How important are tariffs, and how important are factors like infrastructure and institutions in explaining the failure of non-performing developing countries to integrate into the trading system? To address this set of questions, we have explored the evolution of trade across a panel spanning bilateral trade flows from 1988 to 2002. We have examined not just trade volumes where trade is observed, but also the determinants of zero trade flows. This has involved estimating a selection model with maximum likelihood techniques, where we examine the probability of a given bilateral trade occurring and also the determinants of trade volumes. We work with a gravity model in this context, where the standard right hand side variables have been expanded to include indexes of both physical infrastructure and institutional development. Our results indicate that while the evidence on institutions is somewhat mixed, at the same time, variation in infrastructure 
relative to the expected values for a given income cohort is strongly linked to exports. Indeed, sample variation in basic infrastructure (communications and transportation) explains substantially more of the overall sample variation in exports than do the trade barriers faced by developing countries. This points to a more nuanced/diversified strategy, focused not just on WTO-related market access conditions but trade facilitation (infrastructure and institutions) linked to trade performance. 


\section{References}

Anderson, J. (1979). "A Theoretical Foundation for the Gravity Equation." American Economic Review 69(March): 106-116.

Anderson, J., And D. Marcoulller (2002). "Insecurity and the Pattern of Trade: An Empirical Investigation." The Review of Economics and Statistics 84: 342-352.

Anderson, J. And E. van Wincoop (2003). "Gravity with Gravitas: A Solution to the Border Puzzle." American Economic Review 93(1): 170-192.

Bhagwati, J. (1978). Anatomy and Consequences of Exchange Control Regimes. Cambridge, Mass.: Ballinger Publishing Co. for the National Bureau of Economic Research.

Boatman, K.T. (1992). Telecommunications System Quality and Export Performance. doctoral dissertation, University of Maryland: College Park.

Bougheas, S., Demetriades, P. and E. Morgenroth (1999). "Infrastructure, transport costs and trade." Journal of International Economics 47: 169189.

Chang, R., Kaltani, L., and N. Loayza (2005). "Openness can be good for Growth: The Role of Policy Complementarities."World Bank policy research working paper no 3763. September.

Clair, G., G. Gaulier, T. Mayer, and S. Zignago (2004). "Notes on CEPII's distances measures." CEPII: Paris.

Coe, D.T., A. Subramanian, N.T. and Tamirisa (2002). "The missing globalisation puzzle." IMF Working Paper WP/02/171.

DeardorfF, A. (1988). "Determinants of Bilateral Trade: Does Gravity Work in a Neoclassical World?"in J. Frankel ed., The Regionalization of the World Economy. University of Chicago for the NBER, 1998.

Depken II, C.A. And R.J. Sonora (2005). "Asymmetric Effects of Economic Freedom on International Trade Flows." International Journal of Business and Economics 4(2): 141-155.

Disdier, A.C. and K. Head (2003). "Exaggerated Reports on the Death of Distance: Lessons from a Meta-Analysis. " mimeo, TEAM, Université de Paris I Panthéon Sorbonne.

Dollar, D. And A. KraAy (2002). "Institutions, Trade, and Growth." Journal of Monetary Economics. 50: 133-162. 
Dollar, D. And A. KraAy (2004). "Trade, Growth, and Poverty." Economic Journal 114: F22-F49.

EDwards, S. (1993). "Openness, Trade Liberalization, and Growth in Developing Countries." Journal of Economic Literature 31:3: 1358-1393.

Evenett, S.J. And W. Keller (2002). "On Theories Explaining the Success of the Gravity Equation." Journal of Political Economy. 110(2): 281-316.

Evenett, S. And A.J. Venables (2003). "Export Growth in Developing Countries: Market Entry and Bilateral Trade." working paper, London School of Economics.

Feenstra, R. (2004). Advanced International Trade: Theory and Evidence. Princeton University Press: Oxford.

Felbermayr, G.J. \& W. Kohler (2004). "Exploring the Intensive and Extensive Margins of World Trade." CESifo Working Paper Series CESifo Working Paper No. 1276, CESifo GmbH.

Francois, J.F. And D. Roland-Holst (1997). "Scale Economies and Imperfect Competition." in J. Francois and K. Reinert, editors, Applied Methods for Trade Policy Analysis: A Handbook. Cambridge University Press: Cambridge.

Francois, J.F. AND J. WoERZ (2006). "Mixed complimentarity programmingbased panel estimation of non-tariff barriers."World Bank discussion paper.

Freund, C. And B. Bolaky (2002). "Trade, Regulations, and Growth."World Bank policy research working paper no. WPS 3255, November.

Greenaway, D. W. Morgan, and P. Wright (2002). "Trade Liberalization and Growth in Developing Countries." Journal of Development Economics 67: 229-244.

Greene, W.H. (2003). Econometric Analysis: 5th edition (Chapter 22). Prentice Hall: New Jersey.

GWartney, J. And R. LaWson (2005). Economic Freedom of the World: 2005 Annual Report. The Fraser Institute: Vancouver. Data retrieved from www.freetheworld.com.

Havemann, J. and D. Hummels (2004). "Alternative Hypotheses and the Volume of Trade: the Gravity Equation and the Extent of Specialization." Canadian Journal of Economics 37(1): 199-218.

Heckman, J. (1979). "Sample Selection Bias as a Specification error." Econometrica 47: 153-161. 
Hertel, T.W., E. Ianchovichina, And B.J. McDonald (1997) "MultiRegion General Equilibrium Modeling." in J. Francois and K. Reinert, editors, Applied Methods for Trade Policy Analysis: A Handbook. Cambridge University Press: Cambridge.

Hummels, D. And Klenow, P.J. (2005). "The Variety and Quality of a Nation's Exports" The American Economic Review 95(3): 704-723.

Kaufmann, D. A. KraAy and M. Mastruzzi (2005). "Governance Matters IV: Governance Indicators for 1996-2004 "World Bank Policy Research Working Paper Series No. 3630.

Krueger, A. O. (1978). Foreign Trade Regimes and Economic Development: Liberalization Attempts and Consequences. Cambridge, Mass.: Ballinger Publishing Co. for the National Bureau of Economic Research.

Levchenko, A. (2004). "Institutional Quality and International Trade."IMF Working Paper 04/231.

Limo, N. And A.J. Venables (2001). "Infrastructure, Geographical Disadvantage, Transport Costs and Trade." World Bank Economic Review 15: 451-479.

Mtys, L. (1997). "Proper Econometric Specification of the Gravity Model." The World Economy 20:363-368.

Obstfeld, M. And K. Rogoff (1995). "Exchange rate Dynamics Redux" Journal of Political Economy 102(June 1995): 624-660.

Ranjan, P. And J.Y. LEe (2003). "Contract Enforcement and the Volume of International Trade in Different Types of Goods." mimeo, UC Irvine.

Roberts, M.J. And J.R. Tybout (1997). "The Decision to Export in Colombia: An Empirical Model of Entry with Sunk Costs." The American Economic Review 87(4): 545-564.

Rodriguez, F. And D. Rodrik (1999). "Trade policy and economic growth: a skeptic's guide to the cross-national evidence." CEPR discussion paper 2143.

Rodrik, D., Subramanian, A. and F. Trebbi (2004). "Institutions Rule: The Primacy of Institutions over Geography and Integration in Economic Development." Journal of Economic Growth 9: 131-165.

Sala-I-Martin, X. (2006). "The World Distribution of Income: Falling Poverty and... Convergence, Period. "Quarterly Journal of Economics 121(2): 351-398.

Santos Silva, J.M.C And S. Tenreyro (2005). "The Log of Gravity." Review of Economics and Statistics forthcoming. 
Wacziarg, R. AND K.H. Welch (2003). "Trade Liberalization and Growth: New Evidence" NBER working paper 10152, December.

Wilson, J.S., Mann, C.L., And T. Otsuki (2004). "Assessing the potential benefit of trade facilitation : A global perspective."World Bank Working Paper no. WPS 3224.

World BAnk (1987). World Development Report 198\%. New York: Oxford University Press for the World Bank. 
Table 1: Principal components weighting factors

\begin{tabular}{|l|c|c|}
\hline & component 1 & component 2 \\
\hline & & \\
Institutions & & \\
Size of government & -0.189 & 0.710 \\
Legal system property rights & 0.673 & -0.143 \\
Sound money & 0.325 & 0.372 \\
Freedom to trade internationally & 0.620 & 0.040 \\
regulation & 0.147 & 0.579 \\
\cline { 2 - 3 } cumulative proportion & 0.349 & 0.697 \\
\hline & & \\
Infrastructure & & \\
& & \\
Airtransport & 0.053 & 0.663 \\
Fixedmobilesubscribers & 0.463 & -0.038 \\
Mobilephones & 0.302 & 0.166 \\
Roadspaved & 0.347 & -0.111 \\
Telephonemainlines & 0.460 & -0.047 \\
Telephonemainlinescity & 0.436 & -0.007 \\
Telephonemainlinesemployee & 0.410 & 0.082 \\
Roadstotalnetwork & -0.055 & 0.714 \\
\cline { 2 - 3 } cumulative proportion & 0.567 & 0.771 \\
\hline
\end{tabular}

Source: own calculations. 
Table 2: Regression model variable description

\begin{tabular}{|l|l|}
\hline & \\
$\ln p_{\text {}} p c G D P$ & log of per-capita GDP of partner \\
$\ln r_{-}$cGDP & log of per-capita GDP of reporter \\
$\ln p P O P$ & log of population of partner \\
$\ln r P O P$ & log of population of reporter \\
$\ln T$ & log of tariff: (1+t) \\
$\ln$ dist & the log of distance (km, great circle method) \\
landlocked & landlocked partner \\
comlang_ethno & shared linguistic/cultural heritage \\
colony & reporter and partner had colonial relations \\
$\ln I N F 1$ & partner infrastructure index 1 \\
$\ln I N S 1$ & partner institution index 1 \\
$\ln I N F 2$ & partner infrastructure index 2 \\
$\ln I N S 2$ & partner institution index 2 \\
\hline
\end{tabular}

Table 3: OLS regressions: incomes and index values

\begin{tabular}{|l|c|c|c|c|}
\hline & Infrastructure 1 & Infrastructure 2 & Institution 1 & Institution 2 \\
ln GDP95percapita & 1.198 & 0.293 & 0.648 & 0.187 \\
& $(0.018)^{* * *}$ & $(0.008)^{* * *}$ & $(0.011)^{* * *}$ & $(0.013)^{* * *}$ \\
$\ln$ POP & 0.079 & 0.516 & 0.039 & -0.024 \\
& $(0.016)^{* * *}$ & $(0.007)^{* * *}$ & $(0.011)^{* * *}$ & $(0.013)^{*}$ \\
Constant & -9.609 & -7.001 & -5.11 & -0.85 \\
& $(0.204)^{* * *}$ & $(0.092)^{* * *}$ & $(0.141)^{* * *}$ & $(0.174)^{* * *}$ \\
\hline R-squared & 0.690 & 0.760 & 0.67 & 0.11 \\
\hline
\end{tabular}

Standard errors in parentheses: * significant at 10\%; ** significant at 5\%; *** significant at $1 \%$ 


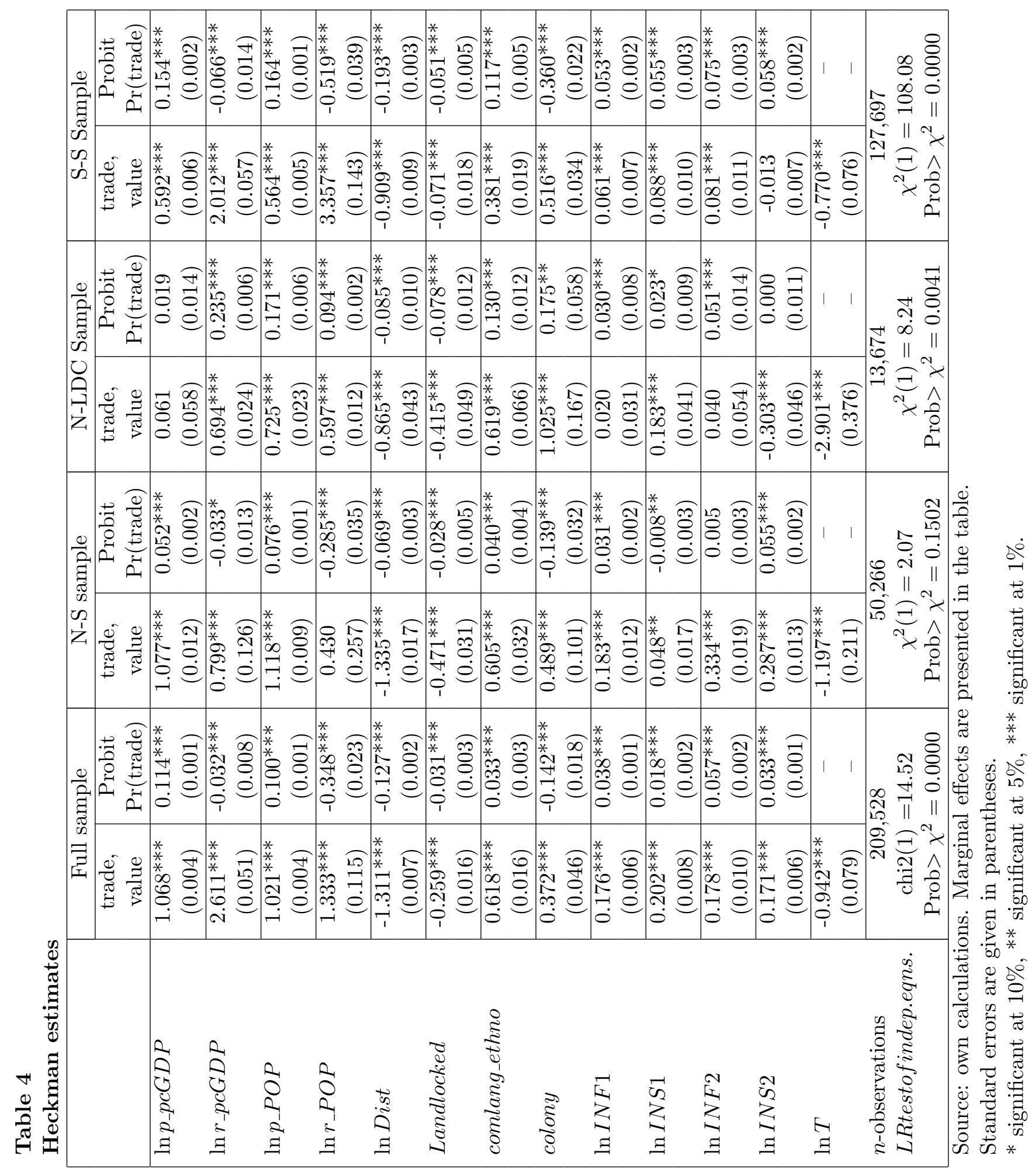


Table 5

OLS estimates

\begin{tabular}{|c|c|c|c|c|}
\hline & $\begin{array}{c}\text { Full } \\
\text { sample }\end{array}$ & $\begin{array}{c}\text { N-S } \\
\text { sample }\end{array}$ & $\begin{array}{l}\text { N-LDC } \\
\text { sample }\end{array}$ & $\begin{array}{c}\text { S-S } \\
\text { sample }\end{array}$ \\
\hline \multirow[t]{2}{*}{$\ln p_{p} c G D P$} & 1.223 & 1.139 & 0.198 & 1.217 \\
\hline & $(0.004)^{* * *}$ & $(0.012)^{* * *}$ & $(0.073)^{* * *}$ & $(0.009)^{* * *}$ \\
\hline \multirow[t]{2}{*}{$\ln r_{p} c G D P$} & 3.335 & 0.959 & 0.651 & 3.368 \\
\hline & $(0.064)^{* * *}$ & $(0.141)^{* * *}$ & $(0.348)^{*}$ & $(0.094)^{* * *}$ \\
\hline \multirow[t]{2}{*}{$\ln p_{P} O P$} & 1.179 & 1.147 & 1.337 & 1.184 \\
\hline & $(0.004)^{* * *}$ & $(0.009)^{* * *}$ & $(0.027)^{* * *}$ & $(0.007)^{* * *}$ \\
\hline \multirow[t]{2}{*}{$\ln r_{P} O P$} & 2.014 & 0.915 & 1.504 & 4.9 \\
\hline & $(0.142)^{* * *}$ & $(0.284)^{* * *}$ & $(0.694)^{* *}$ & $(0.235)^{* * *}$ \\
\hline \multirow[t]{2}{*}{$\ln D i s t$} & -1.517 & -1.404 & -0.609 & -1.815 \\
\hline & $(0.009)^{* * *}$ & $(0.018)^{* * *}$ & $(0.082)^{* * *}$ & $(0.013)^{* * *}$ \\
\hline \multirow[t]{2}{*}{ Landlocked } & -0.302 & -0.5 & -0.666 & -0.199 \\
\hline & $(0.021)^{* * *}$ & $(0.035)^{* * *}$ & $(0.062)^{* * *}$ & $(0.031)^{* * *}$ \\
\hline \multirow[t]{2}{*}{ comlang_ethno } & 0.723 & 0.606 & 0.923 & 0.715 \\
\hline & $(0.019)^{* * *}$ & $(0.035)^{* * *}$ & $(0.092)^{* * *}$ & $(0.029)^{* * *}$ \\
\hline \multirow[t]{2}{*}{ colony } & 0.752 & 0.916 & 1.143 & 1.017 \\
\hline & $(0.055)^{* * *}$ & $(0.093)^{* * *}$ & $(0.214)^{* * *}$ & $(0.143)^{* * *}$ \\
\hline \multirow[t]{2}{*}{$p_{-} I N F 1$} & 0.18 & 0.157 & 0.127 & 0.176 \\
\hline & $(0.008)^{* * *}$ & $(0.013)^{* * *}$ & $(0.039)^{* * *}$ & $(0.012)^{* * *}$ \\
\hline \multirow[t]{2}{*}{$p_{-} I N S 1$} & 0.235 & 0.069 & 0.319 & 0.222 \\
\hline & $(0.010)^{* * *}$ & $(0.019)^{* * *}$ & $(0.052)^{* * *}$ & $(0.016)^{* * *}$ \\
\hline \multirow[t]{2}{*}{$p_{-} I N F 2$} & 0.163 & 0.371 & 0.176 & 0.242 \\
\hline & $(0.012)^{* * *}$ & $(0.021)^{* * *}$ & $(0.069)^{* *}$ & $(0.019)^{* * *}$ \\
\hline \multirow[t]{2}{*}{$p_{-} I N S 2$} & 0.179 & 0.237 & -0.412 & 0.056 \\
\hline & $(0.008)^{* * *}$ & $(0.014)^{* * *}$ & $(0.058)^{* * *}$ & $(0.012)^{* * *}$ \\
\hline \multirow[t]{2}{*}{ Tariffs } & -1.188 & -1.353 & -2.679 & -1.317 \\
\hline & $(0.100)^{* * *}$ & $(0.240)^{* * *}$ & $(0.527)^{* * *}$ & $(0.130)^{* * *}$ \\
\hline \multirow[t]{2}{*}{ Constant } & -56.495 & -20.361 & -25.755 & -79.498 \\
\hline & $(2.028)^{* * *}$ & $(3.617)^{* * *}$ & $(5.013)^{* * *}$ & $(2.635)^{* * *}$ \\
\hline$n$-observations & 138613 & 36578 & 8326 & 69245 \\
\hline$R$-squared & 0.76 & 0.72 & 0.64 & 0.69 \\
\hline
\end{tabular}

Source: own calculations. Standard errors in parentheses.

* significant at $10 \%$; ** significant at $5 \%$; $* * *$ significant at $1 \%$ 
Table 6

Tobit estimates

\begin{tabular}{|c|c|c|c|c|}
\hline & $\begin{array}{c}\text { Full } \\
\text { sample }\end{array}$ & $\begin{array}{c}\mathrm{N}-\mathrm{S} \\
\text { sample }\end{array}$ & $\begin{array}{l}\text { N-LDC } \\
\text { sample }\end{array}$ & $\begin{array}{c}\text { S-S } \\
\text { sample }\end{array}$ \\
\hline \multirow[t]{2}{*}{$\ln p_{p} c G D P$} & 1.029 & 0.907 & 0.154 & 0.938 \\
\hline & $(0.003)^{* * *}$ & $(0.009)^{* * *}$ & $(0.043)^{* * *}$ & $(0.006)^{* * *}$ \\
\hline \multirow{2}{*}{$\ln r_{p} c G D P$} & 0.451 & 0.346 & -0.081 & 0.115 \\
\hline & $(0.044)^{* * *}$ & $(0.096)^{* * *}$ & -0.17 & $(0.055)^{* *}$ \\
\hline \multirow[t]{2}{*}{$\ln p_{P} O P$} & 0.939 & 0.951 & 0.943 & 0.905 \\
\hline & $(0.003)^{* * *}$ & $(0.007)^{* * *}$ & $(0.016)^{* * *}$ & $(0.005)^{* * *}$ \\
\hline \multirow[t]{2}{*}{$\ln r_{P} O P$} & 1.71 & 1.953 & 2.783 & 0.95 \\
\hline & $(0.104)^{* * *}$ & $(0.206)^{* * *}$ & $(0.359)^{* * *}$ & $(0.143)^{* * *}$ \\
\hline \multirow[t]{2}{*}{ lnDist } & -1.209 & -1.039 & -0.45 & -1.283 \\
\hline & $(0.007)^{* * *}$ & $(0.014)^{* * *}$ & $(0.047)^{* * *}$ & $(0.009)^{* * *}$ \\
\hline \multirow[t]{2}{*}{ Landlocked } & -0.214 & -0.345 & -0.427 & -0.174 \\
\hline & $(0.016)^{* * *}$ & $(0.027)^{* * *}$ & $(0.036)^{* * *}$ & $(0.020)^{* * *}$ \\
\hline \multirow[t]{2}{*}{ comlang_ethno } & 0.486 & 0.579 & 0.742 & 0.665 \\
\hline & $(0.015)^{* * *}$ & $(0.026)^{* * *}$ & $(0.052)^{* * *}$ & $(0.019)^{* * *}$ \\
\hline \multirow[t]{2}{*}{ colony } & 0.468 & 0.468 & 1.048 & -0.378 \\
\hline & $(0.044)^{* * *}$ & $(0.074)^{* * *}$ & $(0.136)^{* * *}$ & $(0.094)^{* * *}$ \\
\hline \multirow[t]{2}{*}{$p_{-} I N F 1$} & 0.151 & 0.079 & 0.055 & 0.131 \\
\hline & $(0.006)^{* * *}$ & $(0.010)^{* * *}$ & $(0.023)^{* *}$ & $(0.008)^{* * *}$ \\
\hline \multirow[t]{2}{*}{$p_{-} I N S 1$} & 0.212 & 0.052 & 0.135 & 0.255 \\
\hline & $(0.007)^{* * *}$ & $(0.014)^{* * *}$ & $(0.030)^{* * *}$ & $(0.011)^{* * *}$ \\
\hline \multirow[t]{2}{*}{$p_{-} I N F 2$} & 0.244 & 0.207 & 0.114 & 0.244 \\
\hline & $(0.010)^{* * *}$ & $(0.017)^{* * *}$ & $(0.042)^{* * *}$ & $(0.013)^{* * *}$ \\
\hline \multirow[t]{2}{*}{$p_{-} I N S 2$} & 0.202 & 0.249 & -0.217 & 0.167 \\
\hline & $(0.006)^{* * *}$ & $(0.011)^{* * *}$ & $(0.033)^{* * *}$ & $(0.008)^{* * *}$ \\
\hline \multirow[t]{2}{*}{ Tariffs } & 0.084 & -0.178 & -0.237 & 0.108 \\
\hline & $(-0.075)$ & $(-0.178)$ & $(-0.300)$ & $(-0.087)$ \\
\hline Constant & $\begin{array}{c}-17.24 \\
(0.592) * * *\end{array}$ & $\begin{array}{c}-18.077 \\
(1.202)^{* * *}\end{array}$ & $\begin{array}{c}-17.201 \\
(2144) * *\end{array}$ & $\begin{array}{c}-13.315 \\
(2075) * * *\end{array}$ \\
\hline$n$-observations & 209528 & 50266 & 13674 & 127697 \\
\hline
\end{tabular}

Source: own calculations. Marginal effects are presented in the table. Standard errors in parentheses: *, **, *** significant at 10\%, 5\%, 1\% 
Table 7: Contributions of variations in infrastructure and institutions to overall variation in expected exports

\begin{tabular}{|l|c|c|c|c|}
\hline & full sample & North-South & North-LDC & South-South \\
\hline $\ln I N F 1$ & 0.09 & 0.11 & 0.05 & 0.11 \\
$\ln I N F 2$ & 0.04 & 0.07 & 0.11 & 0.07 \\
$\ln I N S 1$ & 0.06 & 0.02 & 0.11 & 0.08 \\
$\ln I N S 2$ & 0.10 & 0.13 & 0.05 & 0.05 \\
$\ln T$ & 0.05 & 0.02 & 0.12 & 0.04 \\
\hline coeff of variation for exports & 1.30 & 1.15 & 2.88 & 3.14 \\
\hline
\end{tabular}

note: calculated using estimated coefficients and one standard deviation in variable, for marginal effects on $E(\ln (M))$. 
Table 8

Interactions

\begin{tabular}{|c|c|c|c|c|}
\hline & \multicolumn{2}{|c|}{$\begin{array}{l}\text { Infrastructure } \\
\text { interactions }\end{array}$} & \multicolumn{2}{|c|}{$\begin{array}{l}\text { Institution } \\
\text { interactions }\end{array}$} \\
\hline & $\begin{array}{l}\text { trade, } \\
\text { value }\end{array}$ & $\begin{array}{c}\text { Probit } \\
\text { Pr (trade })\end{array}$ & $\begin{array}{l}\text { trade, } \\
\text { value }\end{array}$ & $\begin{array}{c}\text { Probit } \\
\text { Pr (trade })\end{array}$ \\
\hline$l n p_{-} p c G D P$ & $\begin{array}{c}1.081^{* * *} \\
(0.004)\end{array}$ & $\begin{array}{c}0.120^{* * *} \\
(0.001)\end{array}$ & $\begin{array}{c}1.068^{* * *} \\
(0.004)\end{array}$ & $\begin{array}{c}0.113^{* * *} \\
(0.001)\end{array}$ \\
\hline$l n r_{-} p c G D P$ & $\begin{array}{c}2.610^{* * *} \\
(0.051)\end{array}$ & $\begin{array}{c}-0.032^{* * *} \\
(0.008)\end{array}$ & $\begin{array}{c}2.619^{* * *} \\
(0.051)\end{array}$ & $\begin{array}{c}-0.032^{* * *} \\
(0.008)\end{array}$ \\
\hline$l n p_{-} P O P$ & $\begin{array}{c}1.030^{* * *} \\
(0.004)\end{array}$ & $\begin{array}{c}0.102^{* * *} \\
(0.001)\end{array}$ & $\begin{array}{c}1.025^{* * *} \\
(0.004)\end{array}$ & $\begin{array}{c}0.099^{* * *} * \\
(0.001)\end{array}$ \\
\hline$l n r_{-} P O P$ & $\begin{array}{c}1.367^{* * *} \\
(0.114)\end{array}$ & $\begin{array}{c}-0.353^{* * *} \\
(0.023)\end{array}$ & $\begin{array}{c}1.294^{* * *} \\
(0.115)\end{array}$ & $\begin{array}{c}-0.339^{* * *} \\
(0.023)\end{array}$ \\
\hline $\ln$ Dist & $\begin{array}{c}-1.311^{* * *} \\
(0.007)\end{array}$ & $\begin{array}{c}-0.126^{* * *} \\
(0.002)\end{array}$ & $\begin{array}{c}-1.320^{* * *} \\
(0.008)\end{array}$ & $\begin{array}{c}-0.126^{* * *} \\
(0.002)\end{array}$ \\
\hline Landlocked & $\begin{array}{c}-0.261^{* * *} \\
(0.016)\end{array}$ & $\begin{array}{c}-0.035^{* * *} \\
(0.003)\end{array}$ & $\begin{array}{c}-0.257^{* * *} \\
(0.016)\end{array}$ & $\begin{array}{c}-0.041^{* * *} \\
(0.004)\end{array}$ \\
\hline comlang_ethno & $\begin{array}{c}0.622^{* * *} \\
(0.016)\end{array}$ & $\begin{array}{c}0.034^{* * *} \\
(0.003)\end{array}$ & $\begin{array}{c}0.605^{* * *} \\
(0.016)\end{array}$ & $\begin{array}{c}0.037^{* * *} \\
(0.003)\end{array}$ \\
\hline colony & $\begin{array}{c}0.358^{* * *} \\
(0.045)\end{array}$ & $\begin{array}{c}-0.147^{* * *} \\
(0.018)\end{array}$ & $\begin{array}{c}0.365^{* * *} \\
(0.046)\end{array}$ & $\begin{array}{c}-0.149^{* * *} \\
(0.018)\end{array}$ \\
\hline $\ln I N F 1$ & $\begin{array}{l}0.070^{*} \\
(0.030)\end{array}$ & $\begin{array}{c}-0.033^{* * *} \\
(0.006)\end{array}$ & $\begin{array}{c}0.176^{* * *} \\
(0.006)\end{array}$ & $\begin{array}{c}0.040^{* * *} \\
(0.001)\end{array}$ \\
\hline $\ln I N S 1$ & $\begin{array}{c}0.194^{* * *} \\
(0.008)\end{array}$ & $\begin{array}{c}0.017^{* * *} \\
(0.002)\end{array}$ & $\begin{array}{c}0.226^{* * *} \\
(0.041)\end{array}$ & $\begin{array}{c}0.102^{* * *} \\
(0.009)\end{array}$ \\
\hline $\ln I N F 2$ & $\begin{array}{c}1.165^{* * *} \\
(0.048)\end{array}$ & $\begin{array}{c}0.199^{* * *} \\
(0.010)\end{array}$ & $\begin{array}{c}0.181^{* * *} \\
(0.010)\end{array}$ & $\begin{array}{c}0.055^{* * *} \\
(0.002)\end{array}$ \\
\hline $\ln I N S 2$ & $\begin{array}{c}0.165^{* * *} \\
(0.006)\end{array}$ & $\begin{array}{c}0.034^{* * *} \\
(0.001)\end{array}$ & $\begin{array}{c}-0.090^{* *} \\
(0.033)\end{array}$ & $\begin{array}{c}0.224^{* * *} \\
(0.007)\end{array}$ \\
\hline $\ln T$ & $\begin{array}{c}-0.944^{* * *} \\
(0.079)\end{array}$ & & $\begin{array}{c}-0.941^{* * *} \\
(0.079)\end{array}$ & \\
\hline $\ln I N F 1 * \ln g d p p o p$ & $\begin{array}{c}0.017^{* * *} \\
(0.004)\end{array}$ & $\begin{array}{c}0.010^{* * *} \\
(0.001)\end{array}$ & & \\
\hline $\ln I N F 2 * \ln g d p p o p$ & $\begin{array}{c}-0.111^{* * *} \\
(0.005)\end{array}$ & $\begin{array}{c}-0.017^{* * *} \\
(0.001)\end{array}$ & & \\
\hline $\ln I N S 1 * \ln g d p p o p$ & & & $\begin{array}{c}0.032^{* * *} \\
(0.004)\end{array}$ & $\begin{array}{c}-0.024^{* * *} \\
(0.001)\end{array}$ \\
\hline $\ln I N S 2 * \ln g d p p o p$ & & & $\begin{array}{l}-0.003 \\
(0.005)\end{array}$ & $\begin{array}{c}-0.011^{* * *} \\
(0.001)\end{array}$ \\
\hline $\begin{array}{l}n \text {-observations } \\
\text { LRtestofindep.eqns. }\end{array}$ & $\begin{array}{r}20 \\
\chi^{2}(1) \\
\text { Prob }>\lambda\end{array}$ & $\begin{array}{l}28 \\
16.00 \\
=0.0000\end{array}$ & $\begin{array}{r}20 \\
\chi^{2}(1) \\
\text { Prob }>\chi\end{array}$ & $\begin{array}{l}528 \\
=9.68 \\
=0.0019\end{array}$ \\
\hline
\end{tabular}

Marginal effects with std errors in parentheses.

* significant at $10 \%$; ** significant at $5 \%$; $* * *$ significant at $1 \%$ 


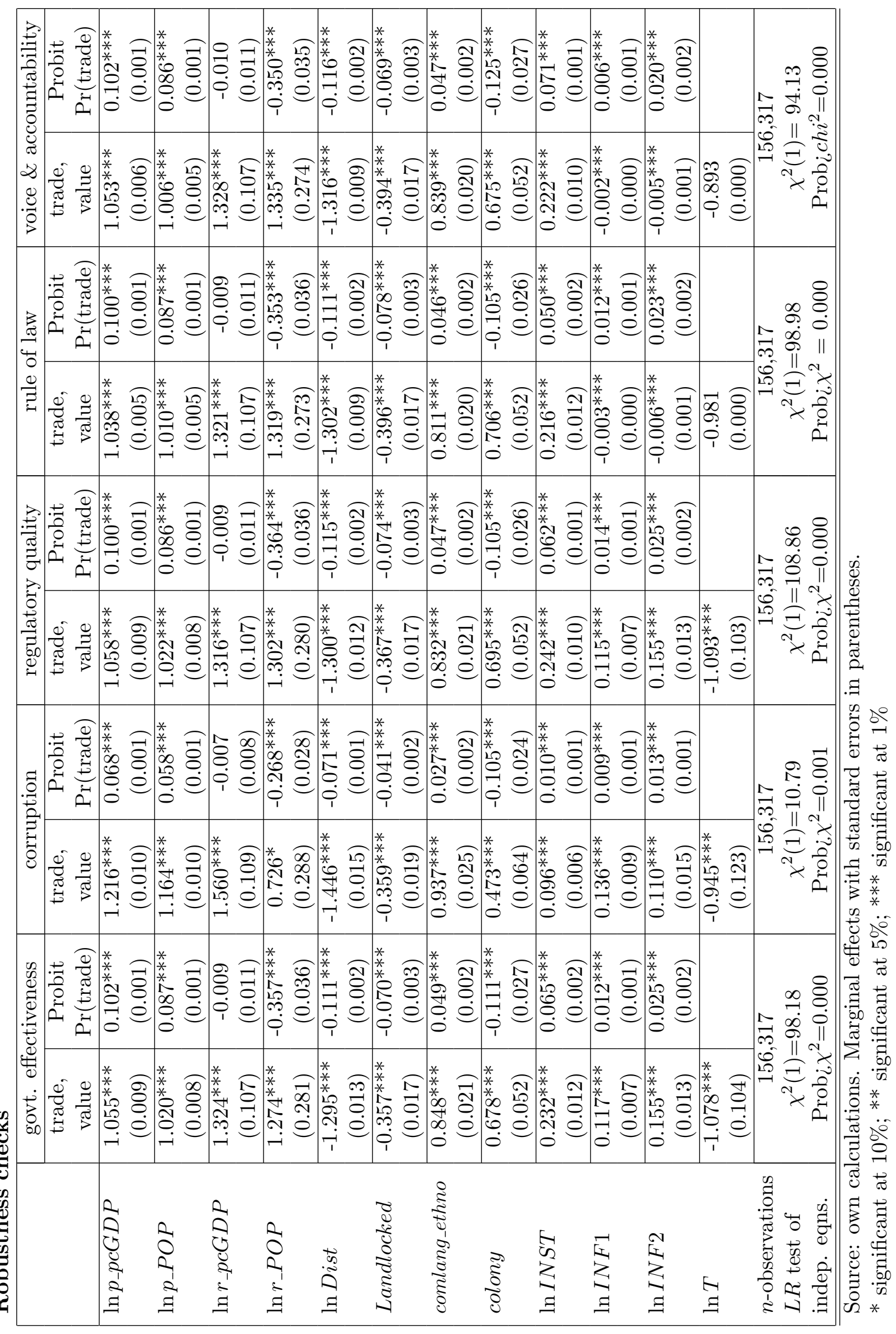


Annex Table A.1: Sample countries

\begin{tabular}{|lll|}
\hline & reporter \& partner & \\
Albania & Guyana & Nepal \\
Argentina & Hong Kong, China & New Zealand \\
Australia & Honduras & Oman \\
Austria & Croatia & Pakistan \\
Belgium & Hungary & Panama \\
Benin & Indonesia & Peru \\
Bangladesh & India & Philippines \\
Bulgaria & Ireland & Papua New Guinea \\
Bahamas, The & Iran, Islamic Rep. & Poland \\
Bolivia & Iceland & Portugal \\
Brazil & Israel & Paraguay \\
Barbados & Italy & Romania \\
Botswana & Jamaica & Russian Federation \\
Central African Republic & Jordan & Rwanda \\
Chile & Japan & Senegal \\
Cote d'Ivoire & Kenya & Singapore \\
Cameroon & Korea, Rep. & El Salvador \\
Congo, Rep. & Kuwait & Slovak Republic \\
Colombia & Sri Lanka & Slovenia \\
Costa Rica & Lithuania & South Africa \\
Cyprus & Latvia & Sweden \\
Czech Republic & Luxembourg & Syrian Arab Republic \\
Germany & Morocco & Chad \\
Dominican Republic & Madagascar & Togo \\
Algeria & Mexico & Thailand \\
Ecuador & Mali & Trinidad and Tobago \\
Egypt, Arab Rep. & Malta & Tunisia \\
Spain & Mauritius & Turkey \\
Estonia & Malawi & Tanzania \\
Finland & Malaysia & Uganda \\
Gabon & Namibia & Ukraine \\
Ghana & Nicaragua & Venezuela \\
Guatemala & Norway & Zambia \\
Fiji & & Zimbabwe \\
Haiti & & \\
\hline
\end{tabular}




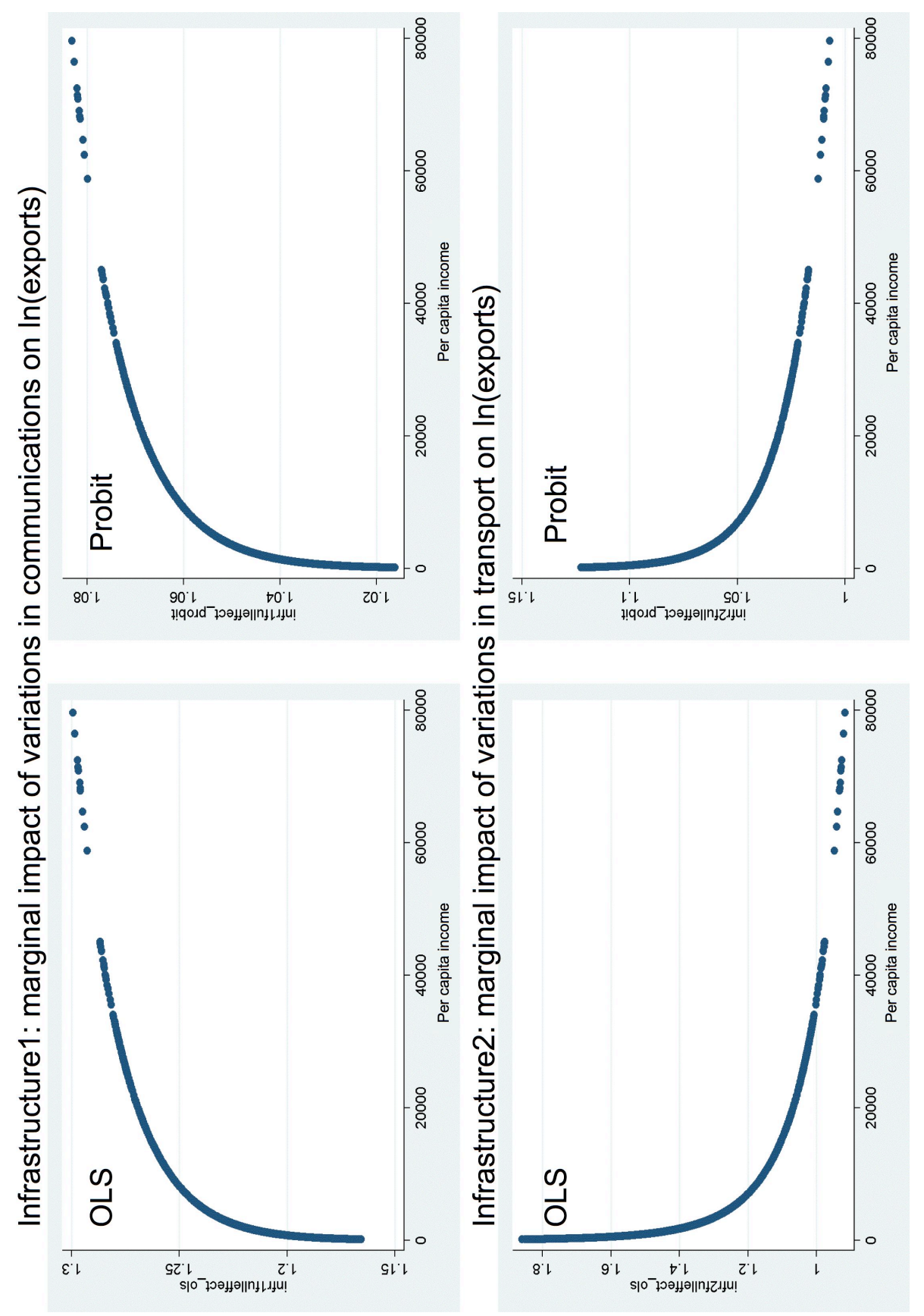

Figure 1: 


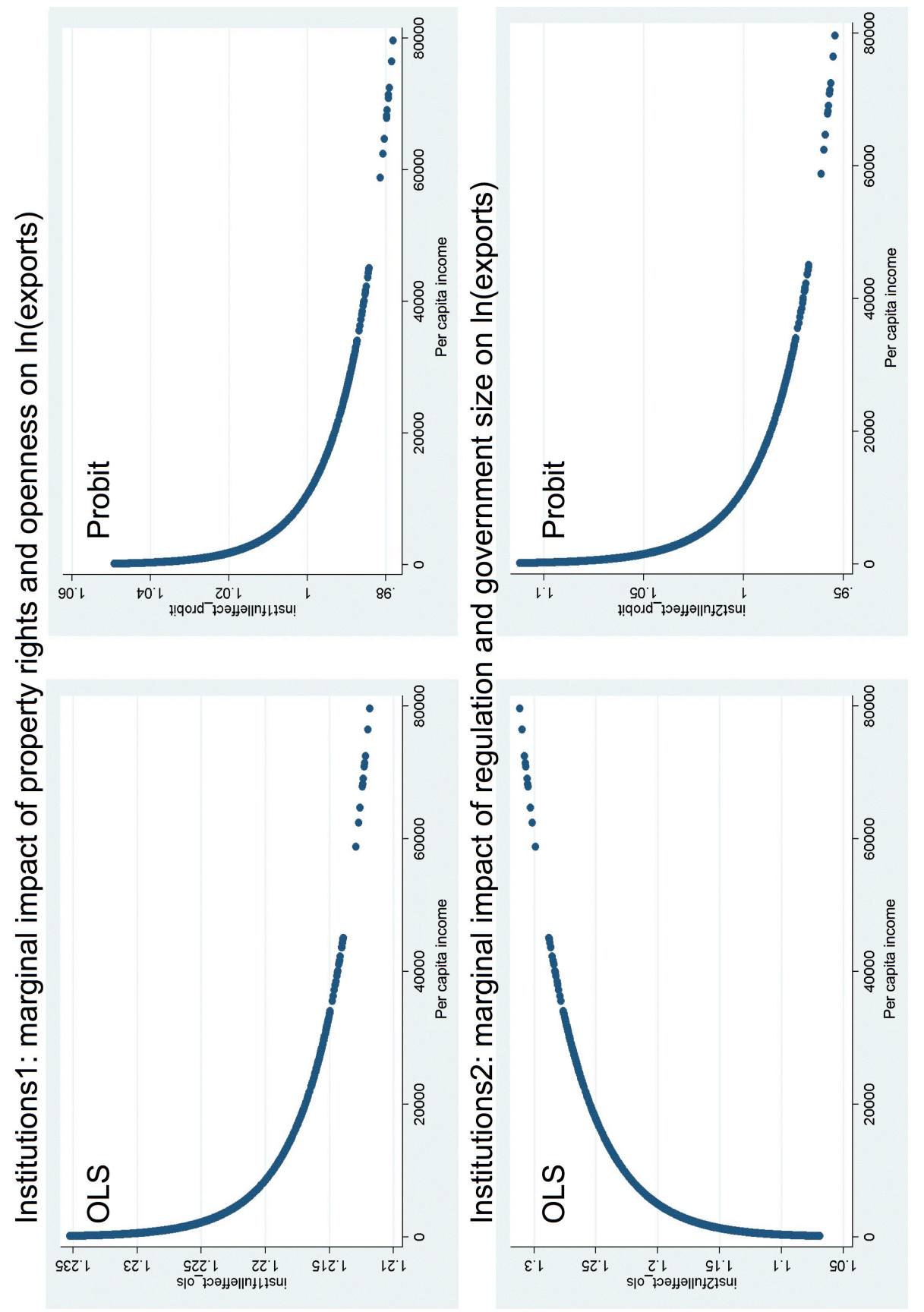

Figure 2: 